cata sakti

imakasih)

Keempat

cata ajaib

bagi kita

enghargai

A. Foss.

Edisi

umanika.

munikasi

Aksara.

mumikasi

Lengkap.

Jrasindo.

thy $A$.

gamisasi:

uku 2).

Empat.

engantar

Aplikasi.

amanika.

Sebuah

Kinerja

rali Pers.

Djokdia.

entang=

tanggal

2018

thuh $7 \%$

in. go id

Industri-

diakses

un 2018 .

\section{RFPRESENTASI KETIDAKADILAN GENDER DALAM FILM SURAT CINTA UNTUK KARTINI}

(ANALISIS SEMIOTIKA DALAM FILM "SURAT CINTA UNTUK KARTINI")

\author{
Jalu Rahman Dewantara \\ Fakultas Ilmu Sosial dan Ilmu Politik \\ Universitas Pembangunan Nasional "Veteran" \\ Yogyakarta
}

\title{
Abstrak
}

Penelitian atas film "Surat Cinta untuk Kartini" ini dilakukan karena di dalamnya berisi hal yang menarik, yakni melihat sisi lain seorang Kartini dari sudut pandang masyarakat masa lalu. Mleski tergolong film fiksi, namun latar sejarah perjuangan Kartini tetap disuguhkan sesuai dengan fakta di lapangan. Penelitian ini melihat bagaimana ketidakadilan gender menimpa sosok perempuan pada umumnya, dan kartini khususnya yang tersaji dalam simbol-simbol dalam film "Surat Cinta antuk Kartini". Jenis penelitian yang digunakan adalah penelitian kualitatif. Sedangkan metode yang digunakan adalah semiotika milik Roland Bathes, yang terdiri dari pemaknaan dua tahap yaitu signifikasi tahap pertama (denotasi) dan signifikasi tahap kedua (konotasi). Validitas yang digunakan peneliti menggunakan 5 elemen yaitu, siapa komunikator, motivasi komunikator, Konteks Fisik dan Sosial, Intertekstual, dan Intersubyektif. Hasil penelitian ini menunjukkan bahwa ketidakadilan gender terjadi karena dominasi patriarki yang termanifestasikan ke dalam bentuk marginalisasi, subordinasi, stertotype, kekerasan psikis, dan kekuasaan kaum lelaki. Hal tersebut mengakibatkan kerugian yang menimpa perempuan. Makna pesan dalam film ini adalah mengajak perempuan untuk berani berjuang mengeapai mimpinya, selain itu untuk masyarakat adalah menyadarkan kepada khalayak bahwa hak perempuan itu sama dengan laki-laki. Saran dari peneliti, bagi para sineas baik itu laki-laki maupun perempuan, hendaknya lebih terbuka lagi dalam memandang fenomena yang terjadi di masyarakat, sehingga dalam membuat dan mengembangkan ide cerita untuk menjadi sebuah makna dalam film letih berkualitas lagi.

Kata Kunci : Semiotika, Roland Barthes, Surat Cinta untuk Kartini, Film, Perempuan, Wanita, Gender, Ketidakadilan

\section{Pendahuluan}

Istilah Gender pertama kali dikenalkan

deh Robert Stoller (1968). Istilah tersebut dikenalkan supaya masyarakat mampu memisahkan pencirian manusia yang didasarkan pada definisi yang berasal dari ciri-ciri biologis. Asm Oakley memiliki pendapat lain tentang istilah gender, yaitu gender adalah bentuk konstruksi sosial yang dibangun masyarakat (Nugroho, 2008:2-3) Anggapan Gender yang berbeda dikemukakan oleh Suzzane Williams, Janet Seed, dan Adeline Mwau. Dalam Oxfam Gender Training Manual dikutip dari (Nugroho, 2008:6), mengartikan bahwa Gender sebagai 
konstruksi atau bentuk sosial yang sebenarnya bukan bawaan lahir sehingga dapat dibentuk atau dirubah tergantung dari tempat, waktu/ zaman, suku/ras/bangsa, budaya, status sosial, pemahaman agama, negara ideologi, politik, hukum, dan ekonomi.

Sebenarnya perbedaan gender tidaklah menjadi masalah selama tidak menimbulkan sebuah ketidakadilan. Namun, prakteknya hal tersebut tetap saja terjadi. Riant Nugroho dalam bukunya : Gender dan Strategi Pengarus Utamaanya di Indonesia, mengungkapkan bahwa ketidakadilan gender merupakan sistem dan struktur di mana kaum laki-laki dan perempuan menjadi korban dari sistem tersebut. Ketidakadilan gender tersebut termanifestasi dalam bentuk , marginalisasi, subordinasi, kekerasan, stereotype, dan beban kerja (Nugroho, $2008 ; 17$ ).

Ada 5 tingkatan di masyarakat yang menjadi wadah terbentuknya manifestasi ketidakadilan gender, yaitu tingkat negara, tempat kerja, adat istiadat, rumah tangga, individu dan masyarakat. Hal ini dapat diambil kesimpulan bahwa ketidakadilan gender sudah mengakar mulai dari keyakinan di masingmasing orang, keluarga, hingga pada tingkat negara yang bersifat global (Nugroho, 2008;1718)

Permasalahan gender di Indonesia menjadi hal klasik. Sejarah perbedaan gender antara laki-laki dan wanita memang telah terjadi proses yang panjang. Tetbentuknya perbedaan ini dikarenakan beberapa hal, diantaranya melalui proses pembentukan, sosialisasi, penguatan, bahkan dikonstruksikan secara sosial dan kultural, melalui ajaran keagamaan dan negara
(Faqih, 2003: 8-9)

Ketidakadilan perlakuan gender beberapa tingkatan yaitu dari tingkatan agama, sosial budaya, ekonomi, dan tangga. Ketidakadilan gender juga dapa marginalisasi, subordinat, stereotipe, ke dan beban ganda (Nugroho, $2008 ; 9-18$

Banyak cara untuk meny perlawanan ketidakadilan gender. satunya adalah melalui film. Film media komunikasi masa yang bersif visual. Media komunikasi ini memusa pada gambar gerak yang memiliki sif tertentu. Sifat media ini juga seperti no tersebut dikarenakan adanya kesanggup memainkan ruang dan waktu, mengem dan mempersingkatnya, menggerakan bebas dalam batas-batas yang telah di (Sobur, 2004:128).

Atas dasar itulah kini bany film khususnya di lndonesia yang lahir tema feminisme dan emansipasi. diantaranya adalah Cut Nyak Dhien ( Hati 7 Cinta 7 Wanita (2010), dan ya baru ini rilis adalah Surat Cinta Untuk (2016). Film-film tersebut memiliki jal: yang sama, yaitu tentang perjuangan par dalam memperoleh haknya.

Penggambaran ketidakadilan salah satunya diangkat oleh Film Sur Untuk Kartini. Secara garis besar, film menunjukkan perjuangan seorang pahlawan emansipasi wanita di It dalam memajukan pendidikan dan ke kaumnya. Kartini sendiri merupakan putri bangsawan Jepara yang lahir pada 1879. Dilahirkan sebagai anak bangsaw 
nembuat dirinya menutup diri dari lingkunganya hastru dari statusnya itulah dia mencoba untuk memajukan masyarakat sekitarnya, khususnya pura wanita. Akan tetapi hal tersebut terhalang karena pada waktu itu status wanita masih begitu rendah dan hanya dianggap sebagai pendamping laki-laki.

Dalam film Surat Cinta Untuk Kartini, hanyak digambarkan bahwa pada jaman dahulu para wanita Jawa masih dipandang sebelah mata. Mereka (wanita Jawa) hanya dianggap sebagai penjaga rumah. Teritorial para wanita tersebut juga hanya dipusatkan di seputaran dapur.

Film Surat Cinta untuk Kartini juga menyoroti tentang hak mendapatkan pendidikan hagi kaum wanita yang masih sulit. Karena pada jeman dahulu wanita tidak boleh berpendidikan lebih tinggi dari pria. Ini juga yang menyebabkan seorang Kartini hanya bisa merasakan bangku sekolah sampai umur 12 tahun. Atas dasar itulah wanita kelahiran Jepara ini berjuang. Perjuangan tersebut tidak hanya untuk kepentingan pribadi, lebih dari itu perjuangkan yang digalakan melalui tulisan tersebut adalah untuk kepentingan seluruh wanita di Indonesia.

Atas jasanyalah, kini wanita Indonesia hisa bebas dalam berkreasi. Mereka (kaum wanita) terutama yang sudah dalam kehidupan yang baik bisa lebih mampu berkarya, tanpa harus takut terhadap tekanan kaum laki-laki.

Film Surat Cinta untuk Kartini dirilis bersamaan dengan Hari Kartini yang jatuh pada tasgal 21 April 2016. Film ini merupakan thsi historical period drama berlatar kehidupan pejuang emansipasi wanita indonesia tersebut. Disutradarai oleh Azhar Kinoi Lubis, film ini mampu menyajikan sosok Kartini (Melayu
Nicole Hall) dari penceritaan tokoh laki-laki, yaitu Sarwadi (Chicco Jerikho). Meskipun bernuansa drama dan fiksi sejarah, namun film ini tetap menyajikan humor-humor ringan dari beberapa tokoh di dalamnya.

Jalan cerita dari film Surat Cinta untuk Kartini dapat dikatakan lain daripada yang lain. Hal ini dikarenakan penceritaan seorang Kartini menggunakan sudut pandang orang pertama aktor pria, yaitu Sarwadi. Dalam film tersebut Sarwadi yang diperankan oleh Chicco Jerikho menjadi seorang duda beranak satu yang bekerja sebagai tukang pos. Pada suatu hari, dia bertugas mengantarkan surat ke dalam rumah bupati. Namun tak dinyana Sarwadi malah bertemu seorang wanita yang ternyata adalah Kartini. Pertemuan inilah yang membawa cerita semakin menarik. Sarwadi ternyata jatuh hati dengan Kartini. Berbagai lika-liku yang dialami oleh Sarwadi dan Kartini digambarkan dalam film ini. Selain itu, banyak adegan yang menggambarkan bahwa perempuan pada masa lalu begitu rendah. Statusnya tidak terlalu kuat dalam masyarakat. Itulah yang menjadi perjuangan Kartini dalam memperjuangkan haknya. Perjuangan itu juga dibantu oleh Sarwadi.

Memang secara jalan cerita film ini tidak sesuai dengan sejarah yang sesungguhnya. Namun, itulah letak keunikan film ini. Karena memang tujuan dari film ini yang juga diamini oleh sang sutradara, Azhar Kinoi Lubis adalah bagaimana membawakan cerita sejarah dengan cara yang berbeda namun tetap enak ditonton. Dengan rating 8,1 (www.imdb.com) karya Azhar Kinoi Lubis ini juga mendapat nominasi ASEAN Skies Prize. Asean Skies Prize merupakan ajang penghargaan insan perfilman 
yang diselenggarakan di Fillipina.

Film Surat Cinta untuk Kartini merupakan salah satu bentuk kampanye penyadaran terhadap wanita-wanita masa kini supaya mampu meniru sosok pahlawan emansipasi tersebut. Hal ini penting, karena dewasa ini Indonesia seperti kehilangan sosok penerus perjuangan Kartini. Meskipun ada, itu hanya sebagian kecil dari ratusan juta wanita Indonesia. Tentu cukup miris. Karena, wanita Indonesia membutuhkan sosok inspirasional yang mampu memotivasi layaknya seorang Kartini.

Film ini juga mengajarkan kepada seluruh khalayak lintas sosial untuk lebih mampu menghargai dan menghormati perbedaan gender. Karena seperti yang kita tahu, perbedaan gender masih menjadi mașalah klasik di Indonesia. Masih banyak budaya masyarakat di Indonesia yang memandang rendah salah satu gender yaitu wanita. Beberapa contoh seperti yang terjadi di Lampung. Pada saat akan menikah, wanita seperti dianggap barang. Artinya, calon mempelai pria akan bertransaksi dengan wali si wanita guna menentukan harga. Hal ini tentu merendahkan harkat dan martabat kaum hawa. Hal lain juga terjadi di beberapa daerah lain di Indonesia. Wanita seakan hanya sebagai obyek patriarki guna memenuhi hasrat kaum adam. Mereka diibaratkan sebagai benda mati yang tidak mampu melawan.

Berkaitan dengan gambaran lemahnya wanita dalam film. Penelitian ini dilakukan pada film Surat Cinta untuk Kartini. Dipilihnya film tersebut karena tema yang diangkat adalah mengenai perjuangan wanita dengan menyisipkan isu ketidakadilan gender. Selain itu, penceritaan sosok Kartini dari sudut pandang tokoh pria juga menjadi poin penting ter: sehingga menjadi pembeda dari film-film yang pernah ada.

Untuk rumusan masalah dalam pen ini adalah Bagaimana gambaran ketidak gender terhadap perempuan dalam Film Cinta untuk Kartini. Melalui numusan m tersebut tentunya penelitian ini bertujuan mengetahui seperti apa gambaran ketidak gender dalam film Surat Cinta untuk Karti Penelitian ini menggunakan semiotika Roland Barthes dan mani ketidakadilangenderyang meliputi margina subordinasi, kekerasan, stereotype, dan kerja (Nugroho, 2008;17). Secara etimo istilah semiotika berasal dari kata $Y$ semeion yang berarti 'tanda', Arti tersebu bermakna bahwa semiotika merupakan yang mempelajari berbagai sistem tanda se bahasa, kode, sinyal, simbol dan lain sebag: Titik perhatian semiotika adalah pada hub antara tanda dan maknanya, serta bagai cara tanda itu dikombinasikan ke dalam kode. Semiotika menunjuk bahwa tek sendiri sebenamya merupakan perlamba dari unsur-unsur lain. Dengan kata lain, sebagai tanda sebenarnya hanyalah bentuk yang dibentuk dan mengacu pada sesua belakangnya (Fiske, 2006:37)

Semiotika sebagai suatu model ilmu pengetahuan sosial yang memahami sebagai sistem hubungan yang memiliki dasar yang disebut dengan 'tanda'. De begitu, semiotika mempelajari hakikat ten keberadaan suatu tanda. Semiotika beru menggali bagaimana bahasa dan komuni memiliki makna berdasarkan asumsi-ast 
tersendiri

Im Kartini

penelitian

idakadilan

ilm Surat

n masalah

uan untuk

dakadilan

artini

an teori

Ianifestasi

ginalisasi,

an beban

imologis,

Yunani,

ebut juga

kan ilmu

la seperti;

bagainya.

aubungan

agaimans

im kode-

teks itu

mbangan

ain, teks

tuk fisik

esuatu di

del dari

mi dunia

liki unit

Dengan

tentang

berusaha

nunikasi

i-asumsi seseorang dalam pemaknaan pesan-pesan. Alex

Sobur dalam bukunya menyebutkan bahwa semiotika dalam pandangannya adalah suatu ilmu atau metode analisis untuk mengkaji tanda (Sobur, 2004: 15).

Salah satu penganut teori semiotika yang sckaligus menjadi acuan yang digunakan dish peneliti adalah Roland Barthes. Barthes memiliki ide-ide yang memberikan gambaran lass mengenai media kontemporer. Dapat Chilang laki-laki asal Prancis ini adalah orang serpenting kedua dalam konsep semiotika di Enopa, tentunya setelah Saussure. Hal tersebut akarenakan sejumlah karya Barthes tidak harya melanjutkan pemikiran Saussure tentang tabungan bahasa dan makna, namun pemikiranya fatru melampaui empunya tersebut, terutama ketika Barthes menggambarkan makna ideologis dari bahasa yang ia ketengahkan sebagai mitos.

Roland Barthes adalah orang pertama yang menyusun model sistematika untuk menganalisa negoisasi dan gagasan makna iteraktif. Inti teori yang dikemukakan Barthes lialab tentang dua tatanan pertandaan (order of scefication) (Fiske, 2006 :118). Dalam teori iersebut Barthes menjadikan semiotika dua tingkatan pertandaan, yakni tingkat tatanan jertama yaitu denotasi dan tatanan kedua dengan membedakan tiga cara kerja : konotasi, mitos, simbolik:

Ketidakadilan gender merupakan sistem tas struktur bagi laki-laki maupun perempuan menjadi korban dari sistem tersebut (Nugroho, 2008-9). Dengan demikian kedua belah pihak memiliki kemungkinan besar untuk tertimpa masalah tersebut. Berikut beberapa ketidak sflinn gender yang menimpa perempuan dilihat dari manifestasinya :

a. Stereotipe

Stereotipe merupakan pelabelan atau penandaan negarif terhadap individu atau kelompokyang tidak sesuai dengan kenyataan empiris yang ada (Nugroho, 2008:12). Label negative secara umum selalu melahirkan ketidakadilan. Salah satu stereotip yang berkembang berdasarkan pengertian gender adalah terhadap salah satu jenis gender perempuan. Hal ini mengakibatkan lahirnya diskriminasi dan berbagai ketidakadilan yang merugikan kaum perempuan. Misalnya pandangan terhadap perempuan yang tugas dan fingsinya hanya melaksanakan pekerjaan yang berkaitan dengan pekerjaan domestik.

b. Beban Kerja

Kaum perempuan memiliki sifat memelihara dan rajin, serta tidak cocok untuk menjadi kepala rumah tangga. Hal tersebut mengakibatkan bahwa semua pekerjaan domestic rumah tangga menjadi tanggung jawab permpuan. Bahkan bagi kalangan kelas bawah, beban yang harus ditanggung oleh perempuam sangatlah berat, apalagi bila perempuan tersebut harus kerja di luar sehingga memiliki beban ganda (Nugroho, 2008: 9-18)

c. Marginalisasi

Marginalisasi merupakan usaha membatasi ruang gerak suatu kelompok. Secara umum, marginalisasiterhadap perempuan ialah usaha membatasi ruang gerak kaum perempuan dalam berbagai aspek. Marginalisasi terhadap kaum perempuan banyak terjadi di berbagai sector. Beberapa diantaranya terjadi di sector publik, sektor domestik, masyarakat atau 
kultur dan negara.

d. Subordinasi

Subordinasi adalah keyakinan bahwa satu jenis kelamin dianggap lebih penting atau lebih utama dibanding jenis kelamin lainya. Sejak jaman dahulu ada pandangan yang menempatkan kedudukan dan peran perempuan lebih rendah dibanding lakilaki. Bakyak kasus dalam tradisi, tafsiran agama maupun dalam aturan birorkasi yang melekatkan perempuan sebagai subordinasi dari kaum laki-laki. Kenyataan tersebut memperlihatkan bahwa ruang gerak perempuan masih terbatas.

e. Violence

Volence atau kekerasan adalah serangan terhadap fisik maupun psikis seseorang. Pada umumnya kekerasan sering menimpa perempuan perbedaan gender. Hal tersebut bisa terjadi karena ada anggapan bahwa perempuan adalah mahluk yang lemah sehingga mudah menjadi sasaran kekerasan.

\section{Metodologi}

Jenis Penelitian yang dilakukan adalah penelitian kualitatif. Penelitian ini menekankan dalam pemaparan tentang situasi dan peristiwa. Data yang ada dinyatakan dalam keadaan sewajarnya atau sebagaimana adanya. Namun, dalam pemaparanya tetap bersifat sistematik, terarah dan dapat dipertanggungjawabkan, sehingga tidak mengurangi sifat ilmiahnya.

Pendekatan yang digunakan adalah analisis kualitatif dengan kajian fokusnya pada analisis semiotika Roland Barthes. Dipilihnya analisis semiotika Roland Barthes karena ada beberapa alasan. Alasan pertama adalah bahwa Roland Bathes tidak hanya melanjutkan pemikiran pendahulunya (Ferdinand Sauss yang berkutat pada bahsa dan makna, lebih lagi Barthes mampu mengembangkanya der adanya makna ideologis dari bahasa yang ketengahkan sebagai mitos. Alasan beriku karena Barthes mampu menyusun $\mathrm{m}$ sistematika untuk menganalisa negoisasi gagasan makna interaktif. Alasan yang $\mathrm{k}$ yaitudua tingkatan yang diterapkan dalam an Roland Barthes (Denotasi dan Konotasi) kaitanya dalam sebuah film. Penjelasanya ad bahwa denotasi merupakan produksi mekan atsa film tentang obyek yang ditangkap kan sedangkan konotasi adalah bagian manus dari proses tersebut.

Analisis data adalah upaya dilakukan dengan cara bekerja dengan mengorganisasikan data, memilah-milah menjadi satuan yang dapat dikelola, mencar menemukan pola, menemukan apa yang per dan apa yang dipelajari, dan memutuskan yang dapat diceritakan kepada orang (Bogdam \& Biklem dalam Moeloeng, 2007: Setidaknya ada lima tahap yang d peneliti dalam melakukan penelitian ini, ya

a. Peneliti akan mengikuti jalan cerita secara fokus sehingga mengerti apa yang ingin disampaikan sutr: kepada penonton.

b. Peneliti merumuskan analisis tahap pertama. Scene yang d dalam analisis nantinya melalui tah pemilihan potongan adegan dalam

c. Peneliti akan mengelompokan berdasarkan indikasi-indikasi berkaitan dengan ketidakadilan g yang menimpa perempuan dalam 
Saussure)

lebih jauh ya dengan yang dia serikutnya n model isasi dan ng ketiga im analissa tasi) erat tya adalah lekanis di p kamera, aanusiawi

a yang gan data, ilah data ncari dan g penting skan apa ing lain. $007 ; 248$ ) ig dilalui yaitu : erita film rti pesan sutradara

is pada dipilih tahapan m film

an data yang gender am film
Surat Cinta untuk Kartini. Selanjutnya akan menganalisis makna dalam film tersebut yang bersifat menjelaskan melalui elemen-elemen film seperti tokoh, lokasi, tingkah laku, dialog, serta iringan musik.

d. Menafsirkan tanda-tanda dari sudut pandang peneliti dengan analisis semiotika tiga formula

e. Penarikan kesimpulan berdasarkan analisis yang dilakukan pada tahap analisis sebelumnya.

Teknik Pengumpulan data dalam senslitian ini menggunakan dua tahap. Yaitu :

2. Analisis Teks Media

Tindo-tanda menurut penafsiran Roland Barthes meriki level dan makna yang berbeda. Penandantingkat pertama disebut denotasi, yang mencakup signifier dan signified. Sedangkan penandaan tingkat kedua adalah konotasi yang pala penanda tingkat kedua menggunakan tanda Uenotasi sebagai signifiermya. Konsep Semiotika - T. Roland Barthes mencakup tanda konotatif s.sk sekedar memiliki makna tambahan, namun rega mengandung kedua bagian denotatif yang melandasi keberadaanya. Sistem pemaknaan saran kedua yang diulas Barthes dibangun Saras sistem lain yang telah ada sebelumnya dan Sscbut dengan konotatif yang dibedakan dari Senotatif, pemaknaan tataran pertama.

\section{b. Studi Pustaka}

Dalam Kamus Besar Bahasa Indonesia (KBBI), pengertian studi pustaka adalah penelitian ilmiah. Merujuk dari pengertian tersebut, maka pola yang dilakukan adalah dengan melakukan penelusuran literatur. Penelusuran ini guna mencari informasi mengenai teori-teori semiotika, film, gender dan sejenisnya yang mendukung penelitian ini.

\section{Pembahasan}

Secara ringkas, Film surat Cinta untuk Kartini dalam pembahasan yang terkait dengan hasil penelitian ini menunjukan bahwa terdapat beberapa bentuk ketidakadilan gender yang menimpa perempuan. Bentuk ketidakadilan tersebut terbagi menjadi beberapa bagian. Yaitu kekuasaan laki-laki atas perempuan yang mengahsilkan ketidakadilan gender berupa kekuasaan implisit, kekuasaan konsensus, dan kekuasaan paksaan. Selanjutnya ada dominasi patriarki yang juga nampak dalam adegan di film ini. Tidak hanya itu saja, ada bentuk-bentuk ketidakadilan gender seperti subordinasi, marginalisasi dan stereotipe turut serta ditampilkan dalam film Surat Cinta untuk Kartini.

Dalam penelitian yang peneliti identifikasi, bahwa nilai-nilai ketidakadilan gender yang ada dalam film Surat Cinta untuk Kartini sesuai dengan manifestasi ketidakadilan gender yang meliputi, marginalisasi, subordinasi, kekerasan, stereotype, dan beban kerja (Nugroho, 2008;17) dan bentuk-bentuk kekuasaan lakilaki atas perempuan. Berikut adalah penjelasan mengenai ketidakadilan gender dalam film Surat Cinta untuk Kartini :

1. Ketidakadilan Gender Bentuk Kekuasaan Implisit

Kekuasaan implisit adalah pengaruh kekuatan yang tidak dapat dilihat tetapi dapat 
dirasakan (Surbakti, 1992 : 63). Kekuasaan implisit yang dihadirkan dalam Film Surat Cinta untuk Kartini berkaitan erat dengan pola pikir masyarakat zaman dahulu yang memandang pendidikan merupakan hal tabu bagi perempuan, khususnya perempuan dari golongan masyarakat biasa. Hanya perempuan dari keturunan ningrat saja yang berkesempatan untuk mengenyam pendidikan, itupun juga tidaklah maksimal. Tengok bagaimana Kartini hanya mampu mengenyam pendidikan hingga usia 12 tahun. Selebihnya ia tidak diijinkan karena persoalan tradisi.
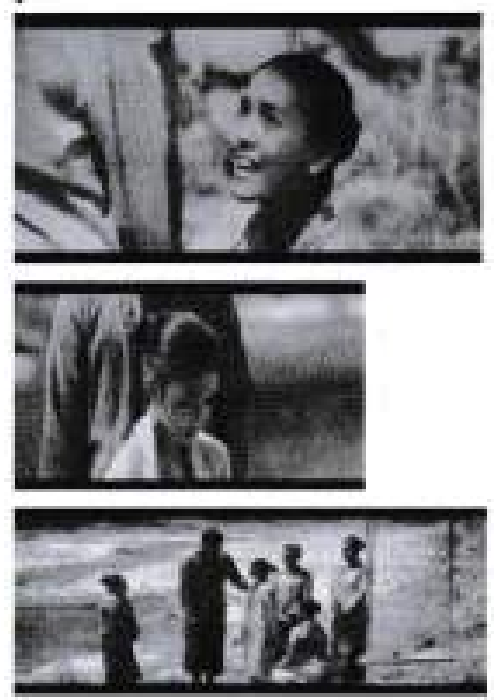

Scene yang menggambarkan bentuk kekuasaan implisit dalam film Surat Cinta untuk Kartini ditunjukan di waktu 32:05$32: 40$. Rincinanya adalah saat Kartini bertanya kepada Ningrum kenapa temanteman Ningrum tidak datang. Ningrum pun menjawab bahwa mereka (temanteman Ningrum) tidak datang karena tidak diizinkan oleh orang tua mereka. Alasan tidak diizinkan karena orang tua dari temanteman Ningrum takut apabila nanti anaknya (perempuan) pandai seperti Kartini, r nanti akan susah dapat jodoh

2. Ketidakadilan Gender Bentuk Kekua Konsensus

Kekuasaan konsensus merup kekuasaan yang menggunakan ss nilai kabaikan bersama, moralitas, ajaran agama sehingga sarana kekua ini memerlukan waktu dan upaya u meyakinkan orang lain sehingga men sadar, dan menaati yang dikehendaki pemegang kekuasaan.

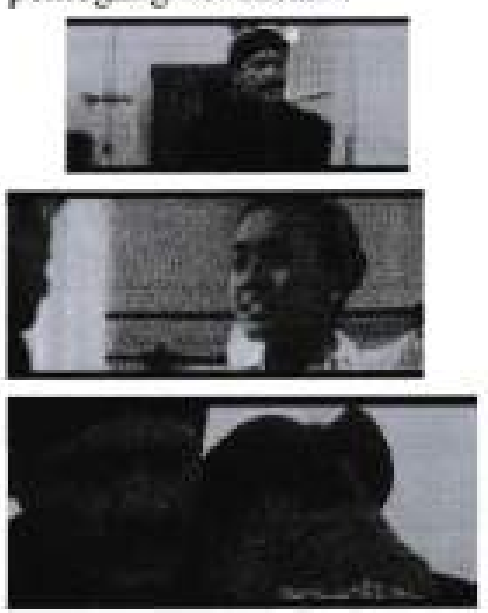

Adegan yang menggambarkan be kekuasaan consensus adalah pada w 1:20:42-1:23:06. Saat itu ayah $\mathrm{Ka}$ Ario Sosroningrat mendatangi $\mathrm{K}_{\bar{A}}$ di kamarnya. Dengan basa basi menanyakan kondisi anak perempu tersebut, namun Kartini hanya d Kemudian Ario langsung menuju p tujuanya mendatangi Kartini yaitu meyakinkan anakya supaya mau men dengan seorang bupati beristri tiga. $\mathrm{K}$. berusaha menolak namun pada akhirny. tidak bisa dan menerima kenyataan. Se kenyataan untuk menikah dengan sec 
tini. maka

Kekuasaan

nerupakan n sarana litas, dan kekuasaan aya unfuk mengerti, daki oleh

n bentuk la waktu Kartini, Kartini asi Ario mpuanya a diam. a pokok ru untuk menikah . Kartini imya dia -Sebuah seorang laki-laki yang telah beristri.

3. Ketidakadilan Gender Bentuk Kekuasaan Paksaan

Kekuasaan paksaan adalah kekuasaan yang menggunakan rasa takut untuk mentaati sebuah kekuasaan. Dalam hal ini bisa berupa takut pada kekuasaan fisik, seperti dipukul, dipenjara, dibunuh. Selain itu ada juga cara non fisik seperti diintimidasi dan dikucilkan (Surbakti, 1992 : 62). Dalam adegan ini kekuasaan paksaan yang diterapkan pekde Kartini adalah kekuasaan paksaan menggunakan rasa takut non fisik (ancaman).

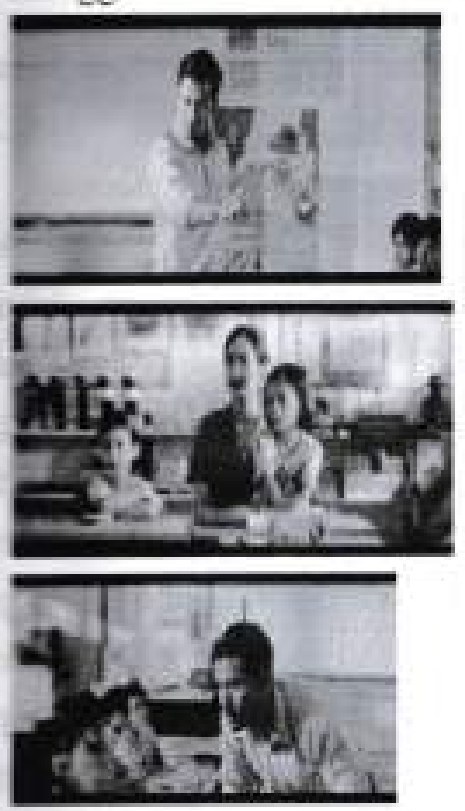

Adegan yang menunjukan adanya kekuasaan paksaan adalah pada waktu 01:11:34-01:12:11. Saat itu Rangga Putra sedang bercerita di kelas seolah-olah dia sebagai pakde dari Kartini. Dalam cerita yang dinarasikan Rangga, Pakde dari Kartini menolak dan memaksa Kartini untuk membatalkan niatanya pergi ke Belanda. Alasan penolakan tersebut adalah karena larar belakang Kartini sebagai Putri Ningrat
Jawa. Selain itu, Pakde dari Kartini juga berujar bahwa bila nanti Kartini jadi pergi ke Belanda dan akhimya pulang, maka dirinya tidak akan dipercaya oleh kaum bumi putera untuk mengajari anak-anak mereka. Dengan penuh penjiwaan, Rangga mampu membawa sosok Pakde yang galak dan penuh emosi sehingga semua orang yang berada di kelas tersebut merasa ketakutan

4. Ketidakadilan Gender Bentuk Dominasi Patriarki

Dalam buku Perempuan dalam Kuasa Patriarki (Adji, 2010:18) menjelaskan bahwa kata patriarki mengacu pada sistem budaya yang didalamnya sistem kehidupan diatur oleh sistem kebapakan. Patriarki merujuk pada susunan masyarakat menurut garis bapak. Ini adalah istilah yang menunjukan ciri-ciri tertentu pada keluarga atau kumpulan keluarga yang diatur, dipimpin dan diperinta oleh kaum bapak atau laki-laki tertua. Kini istilah patriarki secara umum digunakan untuk menyebut "kekuasaan laki-laki", khususnya hubungan kekuasaan laki-laki terhadap perempuan yang di dalamnya berlangsung dominasi laki-laki atas perempuan yang direalisasikan melalui bermacam-macam media dan cara (Bhasin, 1996).
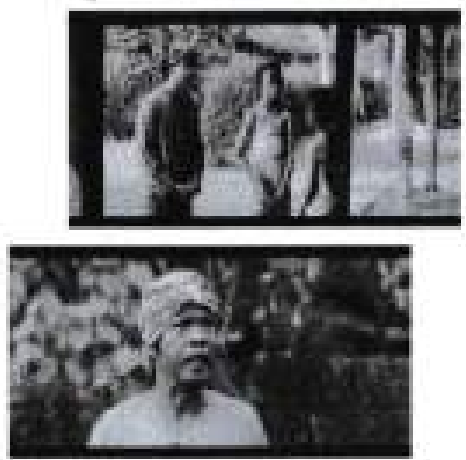


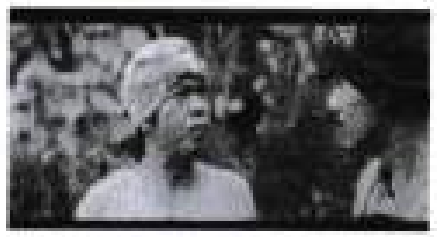

Adegan yang menunjukan bentuk dominasi patriarki adalah waktu 38:53-39:32. Saat itu Sarwadi bersama Ningrum tengah mengajak Imah untuk ikut belajar bersama Kartini. Ningrum membujuk Imah, namun Imah bingung mau ikut atau tidak. Kemudian, Sarwadi menanyakan keberadaan Ayahanda Imah guna membujuknya juga. Ayahanda Imah tiba-tiba datang. Namun sebelum Sarwadi mulai membujuk, Ayahanda Imah sudah menunjukan raut muka ketidaksukaan dan ketidak setujuan bila Imah belajar dengan dalih apa pandai bisa membuat perut kenyang.

5. Ketidakadilan Gender Bentuk Marginalisasi

Marginalisasi merupakan suatu proses pengabaian hak-hak yang seharusnya diterima oleh kaum perempuan sebagai pihak yang termarginalkan (Murniati, 2004 : 20). Hal ini didukung oleh Fakih yang menyatakan bahwa bentuk ketidakadilan gender yang berupa proses marginalisasi perempuan merupakan suatu proses pemiskinan, atas satu jenis kelamin tertentu, dalam hal ini merujuk kepada perempuan yang kemudian diperkuat oleh adat istiadat dan tafsir keagamaan Marginalisasi perempuan dapat terjadi di mana saja seperti di tempat pekerjaan, dalam rumah tangga, masyarakat atau kultur dan negara.
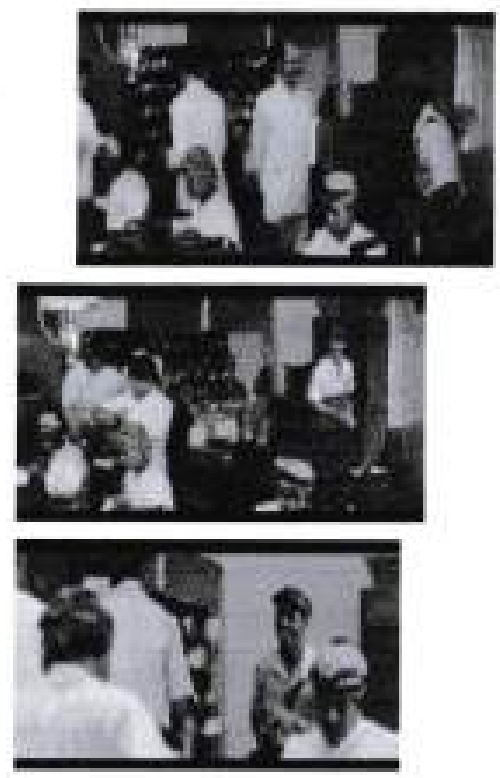

Adegan yang menggambarkan b marginalisasi tersaji pada waktu $5: 44$. Diawali dengan sampainya sarwad sebuah kantor pos. Dengan menger pakaian khas tukang pos jaman $\mathrm{d}$ : Sarwadi nampak bahagia memasuki s ruangan kantor pos. Di dalam ru tersebut terlihat beragam aktivitas pegawainya. Ada yang sedang mencap ada yang mengecek, dan ada pula yang $t$ membawa berkarung-karung surat. Se pegawai yang digambarkan dalam ru tersebut adalah laki-laki dengan ser putih beserta penutup kepala (blangkon

6. Ketidakadilan Gender Bentuk Subordin

Menurut direktorat pemb pendidikan masyarakat (2010), subor perempuan diartikan sebagai ang bahwa perempuan lemah, tidak $m$ memimpin, cengeng dan lain sebag mengakibatkan perempuan jadi n dua setelah laki-laki. Subordinasi a keyakinan bahwa satu jenis ke 
dianggap lebih penting atau lebih utama dibanding jenis kelamin lainya. Sejak jaman dahulu ada pandangan yang menempatkan kedudukan dan peran perempuan lebih rendah dibanding laki-laki. Banyak kasus dalam tradisi, tafsiran agama maupun dalam aturan birorkasi yang melekatkan perempuan sebagai subordinasi dari kaum laki-laki. Kenyataan tersebut memperlihatkan bahwa rang gerak perempuan masih terbatas.

Subordinasi perempuan berawal dari pembagian kerja berdasarkan gender dan dilubbungkan dengan fungsi perempuan sebagai ibu. Kemampuan perempuan ini Ĺgunakan sebagai alasan untuk membatasi perannya hanya pada peran domestik dan pemeliharaan anak - jenis pekerjaan yang silak mendatangkan penghasilan - yang secara berangsur menggiring perempuan sebagai tenaga kerja yang tidak produktif lan tidak menyumbang kepada proses pembangunan.

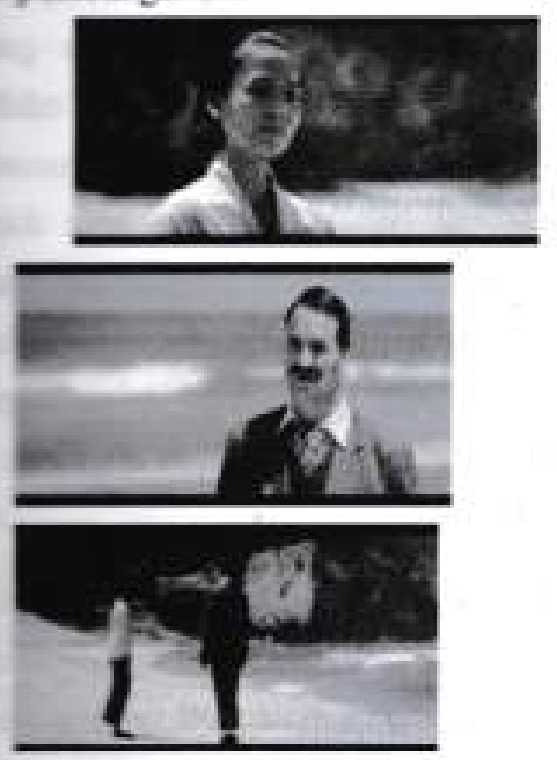

Adegan yang menggambarkan bentuk subordinasi adalah waktu 1:12:11.
1:14:30. Berlokasi di sebuah pantai, Kartini bertemu dengan ayah angkatnya yang merupakan orang Belanda (J.H Abendanon). Pertemuan tersebut untuk membahas perihal keberangkatan Kartini ke Belanda. Akan tetapi, kabar buruk disampaikan oleh ayah angkat Kartini. Ayah angkat Kartini menyarankan Kartini untuk membatalkan niatnya ke Belanda. Hal tersebut karena berbagai macam pertimbangan dan efek dari keberangkatan Kartini ke Belanda.

7. Ketidakadilan Gender Bentuk Stereotipe

Dalam situs bernama wwwilo. org menjelaskan bahwa stereotip gender merupakan generalisasi sederhana tentang atribut, perbedaan dan peran gender dari individu dan atau kelompok. Dengan kata lain bahwa stereotip gender secara otomatis menerapkan asumsi gender kepada orang lain tanpa melihat bukti nyatanya.

Stereotipe merupakan citra baku tentang individu atau kelompok yang tidak sesuai dengan kenyataan empiris yang ada. Label negatif secara umum selalu melahirkan ketidakadilan. Salah satu stereotip yang berkembang berdasarkan pengertian gender adalah terhadap salah satu jenis gender perempuan. Hal ini mengakibatkan lahirnya diskriminasi dan berbagai ketidakadilan yang merugikan kaum perempuan. Misalnya pandangan terhadap perempuan yang tugas dan fungsinya hanya melaksanakan pekerjaan yang berkaitan dengan pekerjaan domestik. 

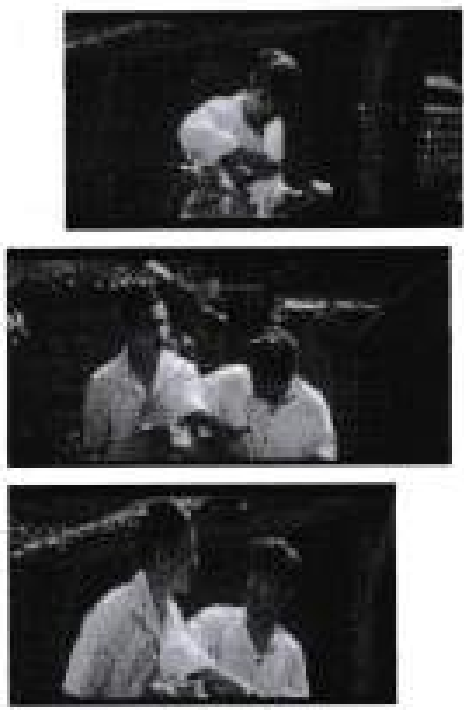

Adegan menunjukan bentuk stereotype adalah pada waktu 13:33-14:17. Saat itu Sarwadi yang tengah menemani sahabatnya Mujur bekerja memahat kayu. Tujuan Sarwadi tidak hanya menemani, lebih dari itu Sarwadi ingin menanyakan kepada Mujur perihal Kartini. Namun, jawaban yang diberikan Mujur justru di luar dugaan. Mujur memberi gambaran bahwa Kartini merupakan orang aneh. Atas ucapan Mujur tersebut, Sarwadi kaget sehingga dirinya yang sedari tadi duduk mulai beranjak berdiri dan kembali menanyakan hal serupa yang justru makin membuat Sarwadi kebingungan.

Secara ringkas, Film surat Cinta untuk Kartini dalam pembahasan yang terkait dengan hasil penelitian ini menunjukan bahwa terdapat beberapa bentuk ketidakadilan gender yang menimpa perempuan. Bentuk ketidakadilan tersebut terbagi menjadi beberapa bagian. Yaitu kekuasaan laki-laki atas perempuan yang mengahsilkan ketidakadilan gender berupa kekuasaan implisit, kekuasaan konsensus, dan kekuasaan paksaan. Selanjutnya ada dominasi patriarki yang juga nampak d adegan di film ini. Tidak hanya itu saja, bentuk-bentuk ketidakadilan gender se subordinasi, marginalisasi dan stereotipe serta ditampilkan dalam film Surat Cinta Kartini.

Terkait dengan teori semiotika Roland Barthes, film Surat Cinta untuk Karti juga menunjukan adanya tanda-tanda sim baik itu secara eksplisit maupun tidak. $\mathrm{H}$ : ditunjukan dari beberapa adegan yang de gamblang menunjukan adanya ketidaka gender yang kemudian mampu dikorela: dengan teori semiotika tersebut. Selain pemaknaan dalam menggunakan teori semi menjadi kunci utama untuk lebih memperd adanya indikasi ketidakadilan gender nampak dalam film ini.

Bentuk-bentuk ketidakadilan gender telah tersaji diatas juga merupakan suatu pr dari sebuah budaya patriarki. Patriarki se memilki definisi yaitu sistem pengelomp masyarakat sosial yang mementingkan keturunan bapak/laki-laki. Patrilineal a hubungan keturunan melalui garis ketur kerabat pria atau bapak. Patriarki juga dijelaskan dimana keadaan masyarakat menempatkan kedudukan dan posisi lak lebih tinggi dari pada perempuan dalam s aspek kehidupan sosial, budaya dan ekonor Kesimpulan

Penelitian mengenai represc ketidakadilan gender dalam Film "Surat untuk Kartini" menghasilkan data temuan mayoritas dapat ditemui berdasarkan indikasi-indikasi penelitian ini. Repres 
pak dalam

saja, ada

er seperti otipe tunut

inta untuk

tika milik

Kartini ini

simbolik

k. Hal ini ig dengan

idakadilan

orelasikan

elain itu,

semiotika

iperdalam

der yang

nderyang

tu produk

ki sendiri

lompokan

can garis

Il adalah

ceturunan

iga dapat

kat yang

laki-laki

m segala

nomi.

resentasi

rat Cinta

an yang

an pada

resentasi sritakadilan gender dalam film "Surat Cinta ant' Kartini" ini tidak terlalu nampak secara lasat mata. Beberapa diantaranya terselip sestra tersembunyi dan perlu ditelaah secara mendalam. Sehingga apabila dikaitkan perihal scidakadilan gender dalam film, maka film ini bei. - termasuk bias gender secara langsung. Biss gender sendiri memiliki arti memihak mas merugikan salah satu jenis kelamin, dalam peselitian ini khususnya adalah perempuan. Fal tersebut dibuktikan dengan tetap besarnya geran perempuan yang ditampilkan. Selain itu, sere-puan dalam film ini juga masih memiliki Lasa untuk mengendalikan dirinya meski dalam seceraga adegan tetap harus menuruti pihak lakiis:

Garis besar makna dan pesan film "Surat Ciare antuk Kartini" adalah perempuan mampu bejung seperti halnya laki-laki, Ketangguhan sakk perempuan yang digambarkan oleh Suriai, mampu terlihat secara nyata dalam film Kartini divisualisasikan sebagai seorang * inita Jawa yang meski harus tunduk dengan butays dan sistem masyarakat, namun tetap mangu memperjuangkan ambisi yang pada wats itu merupakan hal yang belum lazim. 4 mbisi tersebut berupa membuat sekolah wanita unk para pribumi Indonesia (sebutan untuk sesdoduk asli suatu negara). Akan tetapi, dalam mer-jodkan mimpinya tersebut ada rintanganmatzanyang dihadapi. Penghalang-penghalang itilah yang menjadi landasan penelitian yang ne phosuskan pada gambaran ketidakadilan peder dalam film "Surat Cinta untuk Kartini".

Kebanyakan, penghalang-penghalang yang menggambarkan ketidakadilan gender siat flm "Surat Cinta untuk Kartini" tidak ditampilkan secara eksplisit. Perlu ada pemahaman secara mendalam sehingga bisa terasa oleh peneliti. Untuk kandungan makna representasi ketidak adilan gender adalah :

a. Dominasi laki-laki terhadap perempuan, sehingga ia (laki-laki) dapat mengatur kehidupan perempuan. Dominasi lakilaki dalam film ini tidak hanya berkutat mengenai sosok seorang ayah kandung. Di situ digambarkan pula kekuasaan seorang pakde (sebutan untuk kakak dari ayah) terhadap tokoh utama perempuang yaitu Kartini. Aturan dominasi yang dilakukan laki-laki dalam film ini lebih menonjol kepada penentuan masa depan dan kebebasan berekspresi seorang wanita. Hal tersebut muncul karena adanya nilai-nilai patriarki yang menimpa perempuan,

b. Kekuasaan implisit dan kekuasaan paksaan juga merupakan bagian dari konflik yang menyebabkan dominasi patriarki yang justru merugikan kaum perempuan.

c. Pandangan masyarakat zaman dulu (era Kartini hidup) yang menganggap bahwa perempuan hanya bisa mengurusi keperluan rumah tangga. Hal ini menjadikan stigma kepada perempuan yang ingin bebas berkespresi menjadi terkekang.

Pesan yang ingin disampaikan dalam film ini adalah bahwa meski perempuan mengalami banyak tantang untuk mewujudkan cita-citanya, namun apabila tetap berusaha, maka hal tersebut tidak hanya menjadi mimpi belaka. Selain itu film ini juga ingin menyampaikan bahwa 
ketidakadilan gender yang dialami perempuan masa lalu justru menjadikan mereka kuat dan bisa berjaya dan membawa perubahan yang lebih baik.

\section{Daftar Pustaka}

\section{Buku}

Adji, Mubammad, Lina Meilinawati, Baban Banita, 2010, Perempuan dalam Kuasa Patriarki, Bandung

Fakih, Mansour, 2003, Analisis Gender, Pustaka Pelajar. Yogyakarta

Fiske, John, 2006. Cultural and Communication Studies, Jalasutra, Yogyakarta

Moleong. Lexy J, 2005, Metodologi Penelitian Kualitant, Remaja Rosdakarya, Bandung

Murniati, Nunuk, 2004, Getar gender buka kedua : perempuan Indonesia dalam perspeknif agama budaya dam keiuarga, Indonesia Tera, Magelang

Nugroho, Riant, 2008, Gender dan Strateg/ Pengarus-utamaanva di Indonesia, Pistaka Pelajar, Yogyakarta

Sobur, Alex, 2004, Semiotika Komunikasi, Remaja Rosdakarya, Bandung

Surbakti, Ramlan, 1992, Memahami Imu Politik, Gramedia Widya Sarana, Jakarta.

\section{Website}

IMDb, Awards, (http://www.imdb.con tt0050083/awards diakses tangg: Januari 2017)

Hlo, (http:/www.ilo.org/wcmsp5/g public/@asia/@ro-bangkok/ jakarta/documents/presenta wcms_203586.pdf diakses tang: November 2017)

KBBI, (https:/kbbi.webid/n diakses tanggal 17 Oktober

Puslit, Kemsos (https:/puslit.kemsos upload/postifiles diakses tanggu Oktober 2017) 